\title{
Effects of solar UV radiation on photosynthesis of the marine angiosperm Posidonia oceanica from southern Spain
}

\author{
Félix L. Figueroa ${ }^{1, *}$, Carlos Jiménez1 ${ }^{1}$, Benjamín Viñegla1 ${ }^{1}$ Eduardo Pérez-Rodríguez ${ }^{1}$, \\ José Aguilera' ${ }^{1}$, Antonio Flores-Moya ${ }^{2}$, María Altamirano ${ }^{2}$, Michael Lebert ${ }^{3}$, \\ Donat P. Häder ${ }^{3}$ \\ ${ }^{1}$ Departamento de Ecología and ${ }^{2}$ Departamento de Biología Vegetal, Facultad de Ciencias, Universidad de Málaga, \\ Campus Universitario de Teatinos s/n, 29071 Málaga, Spain \\ ${ }^{3}$ Institut für Botanik und Pharmazeutische Biologie, Friedrich-Alexander Universität, Staudstr. 5, 91058 Erlangen, Germany
}

\begin{abstract}
The effects of solar irradiance on the photosynthesis of the marine angiosperm Posidonia oceanica L. Delile were investigated by means of pulse amplitude-modulated (PAM) fluorescence in the Natural Park of Cabo de Gata-Níjar, southern Spain. The study was conducted in 2 different seasons, summer (September 1996) and winter (February 1997). Daily variation in the effective quantum yield $\left(\Delta F / F_{\mathrm{m}}{ }^{\prime}\right)$ was determined in plants growing at $2.5 \mathrm{~m}$ and in plants transferred from $15 \mathrm{~m}$ to 0.5 and $2.5 \mathrm{~m}$ depth. Three different experimental designs were conducted: (1) Incubation of shoots under 3 different solar radiation treatments using cut-off UV filters: full solar radiation (PAR + UV-A + UV-B), solar radiation without UV-B (PAR + UV-A) and solar radiation without UV (PAR); (2) shortterm exposure (30 $\mathrm{min}$ ) to high solar irradiance (photoinhibitory phase) under all treatments followed by transfer fo the plants to low irradiance for $4 \mathrm{~h}$ (recovery phase); (3) Preincubation of plants for $4 \mathrm{~d}$ under the 3 cited treatments followed by short-term exposure $(30 \mathrm{~min})$ to high solar irradiance under PAR + UV-A + UV-B, PAR + UV-A and PAR. A significant decrease in $\Delta F / F_{\mathrm{m}}{ }^{\prime}$ occurred from dawn to noon (18\% in September and only $6 \%$ in February), followed by total recovery during the afternoon in both seasons. The highest decrease in $\Delta F / F_{\mathrm{m}}$ ' occurred in shoots illuminated with PAR + UV-A radiation. This decrease was more pronounced in winter than in summer, and was substantially higher in plants transferred from deep $(15 \mathrm{~m})$ to shallow water than in plants harvested at $2.5 \mathrm{~m}$. Moreover, the recovery in the afternoon was higher in plants incubated at $2.5 \mathrm{~m}$ than in those transferred from $15 \mathrm{~m}$ to shallow waters. In the second set of experiments, short exposure $(30 \mathrm{~min})$ of plants collected from $2.5 \mathrm{~m}$ confirmed that inhibition under PAR + UV-A was higher than under PAR + UV-A + UV-B. In general, full recovery after exposure to high solar irradiance (PAR + UVA + UV-B) occurred only in PAR-treated plants in September. Finally, when shoots of $P$. oceanica were preincubated for $4 \mathrm{~d}$ under PAR, PAR + UV-A or PAR + UV-A + UV-B and then submitted to full solar irradiance at the water surface, the greatest reduction in $\Delta F / F_{m}$ ' was seen in plants grown under PAR, while the lowest occurred in PAR + UV-A + UV-B pretreated plants in both seasons. Recovery was higher in PAR + UV-A + UV$B$ pretreated plants. UV solar irradiance also affected both maximal electron transport rate (ETR) and the initial slope of the ETR-irradiance curves. P. oceanica seems to be well acclimated to high solar irradiance, showing a high capacity for recovery. Solar UV-B might be involved in the impairment and recovery of photosynthesis, since removal of UV-B promoted higher inhibition by solar irradiance. The absence of UV under high PAR for several days resulted in a partial loss of the capacity for photoprotection. We conclude that UV radiation could act in the natural habitat as a trigger for the induction of photoprotective mechanisms against high solar irradiance. The ecological implication of the beneficial role of UV-B in well-acclimated marine plants to high irradiance is discussed.
\end{abstract}

KEY WORDS: Marine angiosperms · PAM-fluorometry $\cdot$ Posidonia oceanica $\cdot$ UV radiation 


\section{INTRODUCTION}

Seagrasses contribute significantly to the productivity of coastal areas in both temperate and tropical waters (Phillips \& McRoy 1980). In particular, the production of the endemic Mediterranean species Posidonia oceanica (L.) Delile has been well studied (Boudouresque et al. 1989). P. oceanica and its leaf epiphytes play a major role in the benthic primary production of the Mediterranean Sea (Pergent et al. 1994). Maximal photosynthetic capacity of this species is in the same range as that of the most productive macroalgae (Enríquez et al. 1995), and it makes a substantial contribution to the organic supply to neritic waters (Alcoverro et al. 1995).

Thinning of the ozone layer is resulting in increased levels of ultraviolet B (UV-B) radiation at the Earth's surface (Booth et al. 1994). Consequently, at present there is a considerable concern about the possible impact that increasing UV radiation (UVR) may have on natural ecosystems, especially marine systems (Smith et al. 1992, Franklin \& Forster 1997). The evaluation of the effect of UV-B on marine macrophyte photosynthesis is crucial for evaluating the flow of carbon in the ocean in the scenario of global climate change (Häder \& Worrest 1991). Seagrasses and benthic macroalgae are static and restricted to their site of growth, thus have no opportunity to avoid high irradiances of photosynthetically active radiation (PAR, $\lambda=400$ to $700 \mathrm{~nm}$ ) or UVR by vertical migration, unlike phyto-

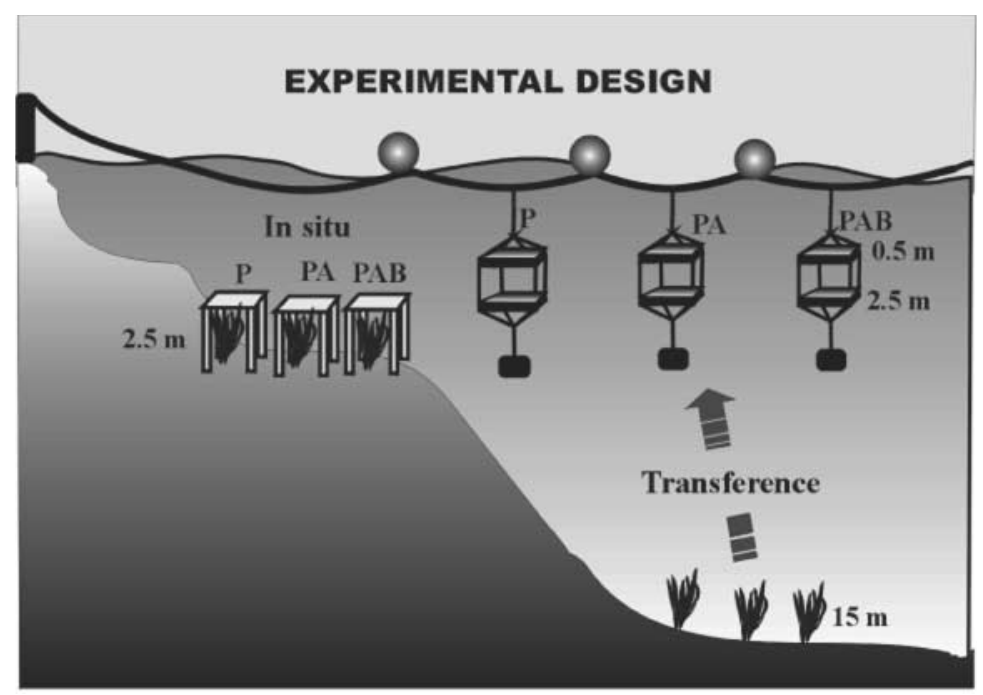

Fig. 1. Design of the different experiments conducted in September 1996 and February 1997 in waters of 'Playazo de Rodalquilar' (Cabo de Gata, southern Spain). Posidonia oceanica from $15 \mathrm{~m}$ were transferred to boxes with different cut-off filters suspended from surface buoys at depths of 0.5 and $2.5 \mathrm{~m}$. Additional plants growing at a depth of $2.5 \mathrm{~m}$ were screened with different UV-cut-off filters. P: PAR; PA: PAR + UV-A; PAB: PAR + UVA + UV-B plankton. This suggests that sublittoral seagrasses may show a lower tolerance to environmental stress, particularly to high irradiances and to UVR, while eulittoral plants should be more adapted to coping with higher UV levels at the surface. Recent studies have described a higher reduction of photosynthetic capacity in subtidal algae than in intertidal algae when exposed to full sunlight (Maegawa et al. 1993, Hanelt et al. 1997, Häder et al. 1998, Hanelt 1998). This reduction in photosynthetic capacity is followed by a decrease in growth rate, increasing pigment photobleaching and tissue damage in some brown and red macroalgae, from shaded and deep areas, after exposure to the sun (Wood 1987, Häder \& Figueroa 1997).

Although many studies have focused on the ecophysiology of Posidonia oceanica, until recently there has been limited information on the effects of UVR on seagrasses in general (Trocine et al. 1981, Dawson \& Dennison 1996, Beer \& Björk 2000). P. oceanica grows preferentially in very clear waters with high penetration of photosynthetically active radiation (PAR) and of $U_{V R}$ thus, we would expect this species to have efficient photoprotection mechanisms against excessive solar irradiance, as has been previously reported for intertidal macroalgae (Hanelt 1996, Figueroa et al. 1997, Flores-Moya et al. 1998).

In this work, the photosynthetic capacity of Posidonia oceanica was estimated by means of the pulse amplitude-modulated (PAM) fluorescence technique, which has been previously used in studies of terrestrial vascular plants and of seaweeds (Büchel \& Wilhelm 1993, Franklin \& Forster 1997, Häder \& Figueroa 1997), and recently also in some seagrasses (Ralph \& Burchett 1995, Dawson \& Dennison 1996, Beer et al. 1998, Ralph et al. 1998, Beer \& Björk 2000). Seasonal and shortterm effects of solar irradiance (with and without UVR) on photosynthesis of $P$. oceanica in the natural environment, determined as changes in the effective quantum yield by means of PAM fluorometry, are discussed.

\section{MATERIALS AND METHODS}

Underwater light field. Underwater PAR and UVR were measured throughout the day by means of a profiling UV radiometer (Biospherical Instruments, Model PUV 500), while surface UVR was monitored every 2 min with a PUV 510A radiometer. The PUV 500 determines downwelling irradiance at 4 UV bands: $305 \pm 1,320 \pm 2 \mathrm{~nm}, 340 \pm 2 \mathrm{~nm}$ and $380 \pm 2 \mathrm{~nm}$, together with PAR by means of a broadband PAR sensor (400 to $700 \mathrm{~nm}$ ). 
The PUV 500 system is equipped with a pressure sensor (depth) and a Sea Tech transmissometer $(25 \mathrm{~cm}$ pathlength). This latter instrument allows determination of light transmission at each depth. The transmissometer was provided with a FFE-3100 LED source with peak wavelength at $660 \mathrm{~nm}$ and spectral line width of $40 \mathrm{~nm}$. The beam attenuation coefficient (c), expressed in $\mathrm{m}^{-1}$, provides a good estimation of the concentration of particulated material (Kirk 1994), and was calculated according to the equation:

$$
C=(\ln T) / \delta x
$$

where $T$ is the transmission and $\delta x$ is the pathlength of the transmissometer $(0.25 \mathrm{~m})$.

The vertical attenuation coefficient of the downward radiation $\left(K_{\mathrm{d}}\right)$ was calculated in the PAR region and in the 4 UV bands by linear regression between the surface $(0.1 \mathrm{~m}$ depth) and the different profiling depths according to the following equation:

$$
K_{\mathrm{d}}=\left(\ln E_{0}-\ln E_{z}\right) / z
$$

where $E_{0}$ is the irradiance at the surface (0.1 m depth) and $E_{z}$ the irradiance at the depth $z$.

In order to calculate the daily integrated irradiance $\left(E_{z}\right)$ of PAR and UVR at different depths $(z)$, the following expression was used:

$$
E_{z}=E_{0} \mathrm{e}^{-\left(K_{\mathrm{d}} z\right)}
$$

where $E_{0}$ was the daily integrated irradiance at the surface $\left(\mathrm{kJ} \mathrm{m}^{-2}\right)$ and $K_{\mathrm{d}}$ the attenuation coefficient of the downward radiation.

UVR for the broad bands 280 to 320 (UV-B) and 320 to $400 \mathrm{~nm}$ (UV-A) was calculated from the irradiance values at 305, 320, 340 and $380 \mathrm{~nm}$, applying the algorithms of Orce \& Helbling (1997):

$$
\begin{aligned}
& \mathrm{UV}-\mathrm{B}=59.5 E_{305}+4.1 E_{320}\left(\mathrm{r}^{2}=0.997, \mathrm{n}=320\right) \\
& \mathrm{UV}-\mathrm{A}=87.4 E_{340}-2.4 E_{380}\left(\mathrm{r}^{2}=0.998, \mathrm{n}=320\right)
\end{aligned}
$$

Photosynthesis. The experiments were conducted in September 1996 and February 1997 on Posidonia oceanica (L.) Delile at El Playazo of Rodalquilar (Natural Park of Cabo de Gata-Níjar, Almería, southern Spain: $\left.36^{\circ} 52^{\prime} \mathrm{N}, 2^{\circ} 12^{\prime} \mathrm{W}\right)$. This sublittoral species shows a seasonal growth pattern with a strong increase from February onwards, with a maximum in spring. In summer, active growth stops until the next spring (Ott 1980). Fig. 1 summarizes the experimental design used.

In situ exposure experiments: External and healthy shoots of Posidonia oceanica were collected at $2.5 \mathrm{~m}$ (subtidal plants). They were then placed on the sea bottom and covered in situ with different UV cut-off filters placed $20 \mathrm{~cm}$ above the plants (Fig. 1). The light treatments used were: (1) full solar irradiance (PAR + UV-A + UV-B); (2) solar irradiance without UV-B (PAR
+ UV-A), and (3) solar irradiance without UVR (PAR). The PAR irradiance was obtained by interposing Ultraphan filters (Digefra $\mathrm{GmbH}$, Munich, Germany) with transmission at $\lambda>395 \mathrm{~nm}$, and will be called Treatment ' $\mathrm{P}$ ' throughout this paper. In order to cut off only UV-B radiation, Folex filters (Folex $\mathrm{GmbH}$, Dreieich, Germany) with transmission at $\lambda>320 \mathrm{~nm}$ were used; this light treatment, whereby the plants received PAR + UV-A will be named 'PA'. The filters absorbed 10\% of the incident radiation; thus an Ultraphan filter 295 (with transmission at $\lambda>295$ ) was used for the PAR + UV-A + UV-B treatment to achieve the same irradiance among treatments; this will be referred to as Treatment 'PAB'. The spectral characteristics of these filters have already been described by Figueroa et al. (1997).

The decay of the effective quantum yield $\left(\Delta F / F_{\mathrm{m}}{ }^{\prime}\right)$ during the day was determined with the PAM fluorometer (see next subsection). The experiments were started $1 \mathrm{~d}$ after deployment of the selective filters, and external leaves of Posidonia oceanica were collected every 2 to $3 \mathrm{~h}$, from sunrise to sunset, after 2 and $4 \mathrm{~d}$ under the different light treatments.

Transference experiments: Posidonia oceanica shoots, consisting of rhizomes with several fascicles of leaves, were collected at $15 \mathrm{~m}$ depth and introduced into custom-made UV-transparent boxes, covered with the cut-off filters described above, and suspended from surface buoys at 0.5 and $2.5 \mathrm{~m}$ (Fig. 1). The shoots were transplanted from their growth site to the experimental area in black plastic bags. Daily cycles of $\left(\Delta F / F_{\mathrm{m}}{ }^{\prime}\right)$ were conducted after 2 and $4 \mathrm{~d}$ of incubation.

Exposure and recovery experiments: Samples of Posidonia oceanica freshly collected from $2.5 \mathrm{~m}$ depth were submitted to short-term exposure (30 $\mathrm{min})$ under full solar irradiance in surface waters (0.05 $\mathrm{m}$ depth) under different Schott UV-cut-off filters (transmission at $\lambda<295,<320$ and $<400 \mathrm{~nm}$ ), and the fluorescence was measured after light treatment and at different times after placing the samples in the shade (recovery period). These experiments were also conducted with $P$. oceanica shoots previously grown for $4 \mathrm{~d}$ under $\mathrm{P}, \mathrm{PA}$ and PAB treatments at $2.5 \mathrm{~m}$ depth.

Fluorometry. The fluorescence parameters were estimated immediately after harvesting by means of a PAM fluorometer (PAM 2000, Waltz) according to Schreiber et al. (1986). The effective quantum yield was calculated as $\Delta F / F_{\mathrm{m}}{ }^{\prime}$, where $\Delta F=F_{\mathrm{m}}{ }^{\prime}-F_{\mathrm{t}}\left(F_{\mathrm{t}}=\right.$ the current steady-state fluorescence, Genty et al. 1989, $F_{\mathrm{m}}{ }^{\prime}=$ maximal fluorescence of light-adapted plants) . The plants were harvested by SCUBA divers and transported to a site where measurements were carried out within 15 min under previously standardised dim-light conditions (ca. $50 \mu \mathrm{mol} \mathrm{m} \mathrm{m}^{-2} \mathrm{~s}^{-1}$ ). During this 15 min period no recovery of the effective quantum yield and no significant differences (Tukey's test, p < 
0.05) from the effective quantum yields of the plants in its growth site were observed (Viñegla 2000).

In order to simplify the presentation of the results, the percentage of inhibition and recovery of effective quantum yield are expressed as:

$$
\begin{aligned}
& \% \text { decrease in } \Delta F / F_{\mathrm{m}}{ }^{\prime}=\left[\left(\Delta F / F_{\mathrm{m}}{ }^{\prime} \text { (morning) }-\Delta F / F_{\mathrm{m}}{ }^{\prime} \text { (noon) }\right) /\right. \\
& \left(\Delta F / F_{\mathrm{m}}{ }^{\prime}(\text { noon) })\right] \times 100 \\
& \% \text { recovery of } \Delta F / F_{\mathrm{m}}{ }^{\prime}=\left[\left(\Delta F / F_{\mathrm{m}}{ }^{\prime} \text { (afternoon) }-\Delta F / F_{\mathrm{m}}{ }^{\prime} \text { (morning) }\right) /\right. \\
& \left.\left(\Delta F / F_{\mathrm{m}}^{\prime}{ }^{\prime} \text { morning) }\right)\right] \times 100
\end{aligned}
$$

these being the morning values measured around dawn (08:00 to 08:30 $\mathrm{h}$, local time), the noon values at 14:00 $\mathrm{h}$ in September and at 13:00 $\mathrm{h}$ in February, and the afternoon values around dusk (18:30 to 19:30 h).

Quantum yield under actinic irradiance, supplied by the red-light diode (LED) of the PAM-2000 fluorometer, was estimated in samples of Posidonia oceanica collected in the late afternoon (after a daily cycle). The shoots were exposed to increasing irradiance of between 0 and $650 \mu \mathrm{mol} \mathrm{m} \mathrm{m}^{-2} \mathrm{~s}^{-1}$ at incubation intervals of $30 \mathrm{~s}$, according to Hanelt (1998). The electron transport rate (ETR) was calculated by multiplying the effective quantum yield $\left(\Delta F / F_{\mathrm{m}}{ }^{\prime}\right)$ by the incident irradiance of PAR $\left(E_{\mathrm{PAR}}\right)$, the absorptance (A) of the samples and a factor of 0.5 , because it is assumed that 4 of the

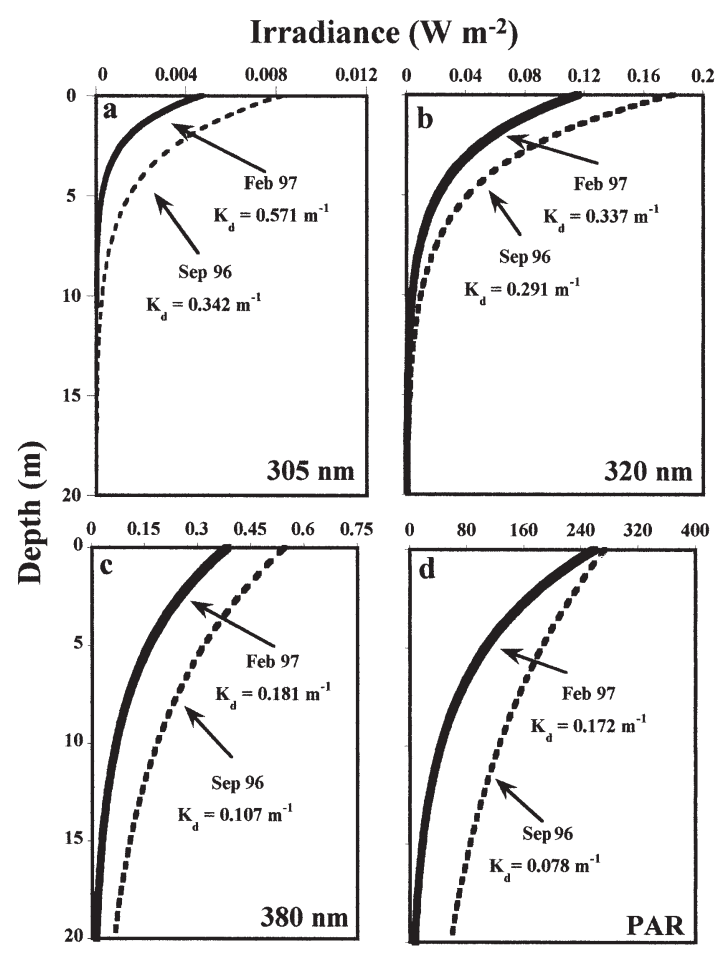

Fig. 2. Vertical profiles of different wavebands of UVR: 305, 320 and $380 \mathrm{~nm}$ and PAR (400 to $700 \mathrm{~nm}$ ) in the waters of Cabo de Gata in September 1996 and February 1997. Attenuation coefficient values $\left(K_{\mathrm{d}}\right)$ for each waveband are indicated
8 electrons necessary to assimilate $1 \mathrm{CO}_{2}$ molecule come from Photosystem II (PSII) (Schreiber et al. 1986):

$$
\mathrm{ETR}=\Delta F / F_{\mathrm{m}}{ }^{\prime} \times E_{\mathrm{PAR}} \times A \times 0.5
$$

Absorptance $(A)$ was calculated from the optical density (OD) value determined in a spectrophotometer (Beckman DU-7) using an opal glass according to Shibata (1957), as follows:

$$
A=1-10^{-\mathrm{OD}}
$$

The average absorptance for the samples collected in February 1997 was 0.85 , and for those collected in September 1996 it was 0.75 .

Fitting of the ETR versus irradiance curves was performed by modifying the non-linear function of Jassby \& Platt (1976), including a term of photoinhibition according to Platt et al. (1980), as follows:

$$
\begin{aligned}
\mathrm{ETR}= & {\left[\mathrm{ETR}_{\text {max }} \times \tanh \left(\left(\mathrm{ETR}_{\mathrm{is}} \times E\right) / \mathrm{ETR}_{\text {max }}\right)\right] } \\
& \times \mathrm{e}^{\left(-\beta \times \mathrm{E}^{-} \mathrm{ETR}_{\text {max }}\right)}
\end{aligned}
$$

where ETR is the electron transport rate, $\mathrm{ETR}_{\max }$ is the saturated ETR, tanh is the hyperbolic tangent function, $\mathrm{ETR}_{\text {is }}$ is the efficiency of the electron transport (initial slope of the ETR vs irradiance curves), $E$ is the incident irradiance, and $\beta$ is the slope of the inhibitory phase. The saturation irradiance for the electron transport $\left(E_{\mathrm{k}}\right)$ was calculated as the intercept between the $\mathrm{ETR}_{\max }$ and $\mathrm{ETR}_{\mathrm{is}}$ values, and the inhibition irradiance $\left(E_{\text {inh }}\right)$ as the intercept between $\mathrm{ETR}_{\max }$ and the exponential inhibitory phase.

Statistical analysis. Data were compared by means of a 2-way (time of day and solar radiation conditions) Model I ANOVA. Tukey's HSD test was applied when significant differences were found among treatments. In all cases, normality of data was assessed by the Kolmogorov-Smirnov test and homogeneity of variance was verified by the Barlett's test when the number of replications was $\mathrm{n} \geq 6$ or the $F_{\max }$ test in the case of $\mathrm{n} \leq 5$ replications. All the statistical tests were carried out in accordance with Sokal \& Rohlf (1995).

\section{RESULTS}

\section{Underwater light field}

Penetration of both PAR and UVR was very high in Cabo de Gata during the experimental period, as expected for very clear coastal waters (Fig. 2) (Type I in Jerlov's classification). The vertical attenuation coefficient decreased from shorter wavelengths (e.g. $305 \mathrm{~nm}$ ) to longer ones (e.g. 320, $380 \mathrm{~nm}$ ) and PAR (Fig. 2). The spectral composition of underwater irradiance was enriched in blue-green wavelengths 

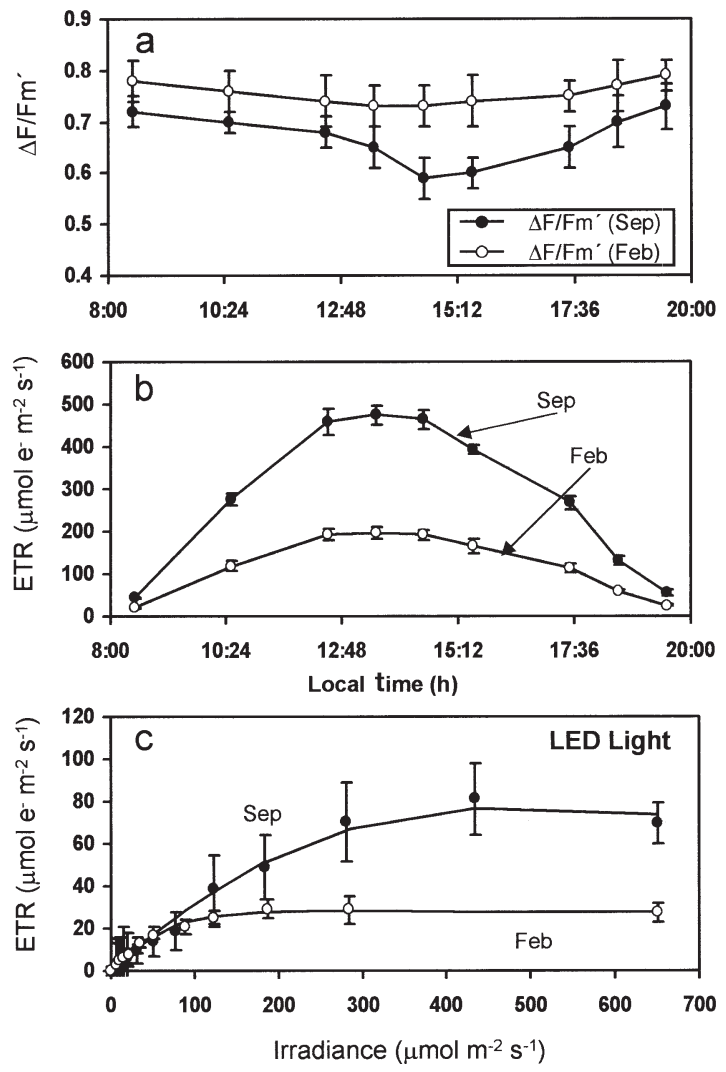

Fig. 3. Posidonia oceanica. Daily variations in (a) effective quantum yield $\left(\Delta \mathrm{F} / \mathrm{F}_{\mathrm{m}}{ }^{\prime}\right)$ and (b) electron transport rate (ETR) in plants collected from $2.5 \mathrm{~m}$ depth in September 1996 and February 1997; (c) ETR versus irradiance, determined by applying the LED light from the PAM 2000 during incubation

periods. Each curve represents the mean of 4 replicates

(data not shown), as expected for very clear coastal waters (Kirk 1994). The attenuation coefficient $\left(K_{\mathrm{d}}\right)$ of UV-B radiation was higher than that of UV-A radiation (Table 1). On the other hand, the $K_{\mathrm{d}}$ of PAR was $\sim 2.3$ to 2.7 and $\sim 1.8$ to 2.0 times lower than that of UV$\mathrm{B}$ and UV-A respectively (Table 1). Higher attenuation coefficients at all wavebands were observed in winter. This is due to a lower transmission and consequently a higher beam-attenuation coefficient in winter than in summer because of the increased presence of particles in winter. In summer, the beam-attenuation coefficient (c) was $13 \%$ higher in winter than in summer; however, the light penetration was $100 \%$ higher in summer than in winter (Table 1). The concentration of particles, estimated from beam-attenuation values, was $1.7 \pm$ $0.1 \mathrm{mg} \mathrm{l}^{-1}$ in February and $1.3 \pm 0.1 \mathrm{mg} \mathrm{l}^{-1}$ in September.

Thus, $1 \%$ surface PAR irradiance penetrated to $59 \mathrm{~m}$ in September and $25 \mathrm{~m}$ in February (Table 1) while $1 \%$ of UV-A irradiance penetrated to ca. $30 \mathrm{~m}$ in September and $14 \mathrm{~m}$ in February. Finally, 1\% UV-B reached $\sim 22 \mathrm{~m}$ in September and $11 \mathrm{~m}$ in February (Table 1).

The weekly integrated irradiance of PAR and UVR was calculated at the different depths at which the experiments were conducted, i.e. $0.5,2.5$ and $15 \mathrm{~m}$ (Table 1). The surface weekly integrated irradiance was 1.6 times higher in September than in February for PAR, 2.3 for UV-A and 5.4 for UV-B. The ratio UVR/PAR was 1.5 times higher in summer than in winter, resulting in higher the UV signals.

\section{Daily cycles of effective quantum yield and electron transport rate (ETR)}

The effective quantum yield in Posidonia oceanica growing at $2.5 \mathrm{~m}$ depth decreased from morning to noon, recovering in the afternoon (Fig. 3a). The decrease in $\Delta F / F_{\mathrm{m}}^{\prime}$ at noon was significantly higher (Tukey's test, $\mathrm{p}<0.01)$ in September $(18 \%)$ than in February (6\%), and full recovery occurred in the after-

Table 1. Attenuation coefficient of downward radiation $\left(K_{\mathrm{d}}\right.$ in $\mathrm{m}^{-1}$ ) for PAR (400 to $700 \mathrm{~nm}$ ), UV-A (320 to $400 \mathrm{~nm}$ ) and UV-B $(280$ to $320 \mathrm{~nm})$; water transmission $(T)$; beam attenuation coefficient $(c)$; depth at which $1 \%$ of surface irradiance is reached $(h)$ for PAR, UV-A and UV-B; and weekly dose at the water surface and at the different depths in which the experiments were conducted $(0.5,2.5$ and $15 \mathrm{~m})$ in September 1996 and February 1997

\begin{tabular}{|c|c|c|}
\hline Variable & 18-25 Sep 96 & 8-15 Feb 97 \\
\hline $\begin{array}{l}\boldsymbol{K}_{\mathbf{d}}(\mathrm{PAR})\left(\mathrm{m}^{-1}\right) \\
(\mathrm{UV}-\mathrm{A})\left(\mathrm{m}^{-1}\right) \\
(\mathrm{UV}-\mathrm{B})\left(\mathrm{m}^{-1}\right)\end{array}$ & $\begin{array}{l}0.078 \pm 0.008 \\
0.154 \pm 0.080 \\
0.210 \pm 0.011\end{array}$ & $\begin{array}{l}0.172 \pm 0.044 \\
0.318 \pm 0.020 \\
0.404 \pm 0.039\end{array}$ \\
\hline $\boldsymbol{T}(\%)$ & $84.750 \pm 2.185$ & $80.160 \pm 0.298$ \\
\hline $\mathbf{c}\left(\mathrm{m}^{-1}\right)$ & $0.780 \pm 0.060$ & $0.890 \pm 0.070$ \\
\hline $\begin{array}{l}\boldsymbol{h}(\mathrm{PAR})(\mathrm{m}) \\
(\mathrm{UV}-\mathrm{A})(\mathrm{m}) \\
(\mathrm{UV}-\mathrm{B})(\mathrm{m})\end{array}$ & $\begin{array}{l}59.040 \pm 4.210 \\
29.900 \pm 2.345 \\
21.930 \pm 2.657\end{array}$ & $\begin{array}{l}25.440 \pm 2.546 \\
14.480 \pm 1.387 \\
11.399 \pm 0.950\end{array}$ \\
\hline \multicolumn{3}{|c|}{ Weekly dose $\left(\mathrm{kJ} \mathrm{m}^{-2}\right)$} \\
\hline $\begin{array}{c}\text { Surface } \\
\text { PAR } \\
\text { UV-A } \\
\text { UV-B }\end{array}$ & $\begin{array}{r}60578.82 \\
9612.36 \\
259.91\end{array}$ & $\begin{array}{r}38128.39 \\
4215.20 \\
48.09\end{array}$ \\
\hline $\begin{array}{c}0.5 \text { m } \\
\text { PAR } \\
\text { UV-A } \\
\text { UV-B }\end{array}$ & $\begin{array}{r}58260.90 \\
8899.00 \\
233.90\end{array}$ & $\begin{array}{r}31346.38 \\
3236.00 \\
35.36\end{array}$ \\
\hline $\begin{array}{c}2.5 \mathrm{~m} \\
\text { PAR } \\
\text { UV-A } \\
\text { UV-B }\end{array}$ & $\begin{array}{r}49840.00 \\
6540.00 \\
153.70\end{array}$ & $\begin{array}{r}21825.93 \\
1713.16 \\
15.76\end{array}$ \\
\hline $\begin{array}{c}15 \text { m } \\
\text { PAR } \\
\text { UV-A } \\
\text { UV-B }\end{array}$ & $\begin{array}{r}18801.66 \\
954.13 \\
11.14\end{array}$ & $\begin{array}{r}2524.40 \\
35.74 \\
0.11\end{array}$ \\
\hline
\end{tabular}



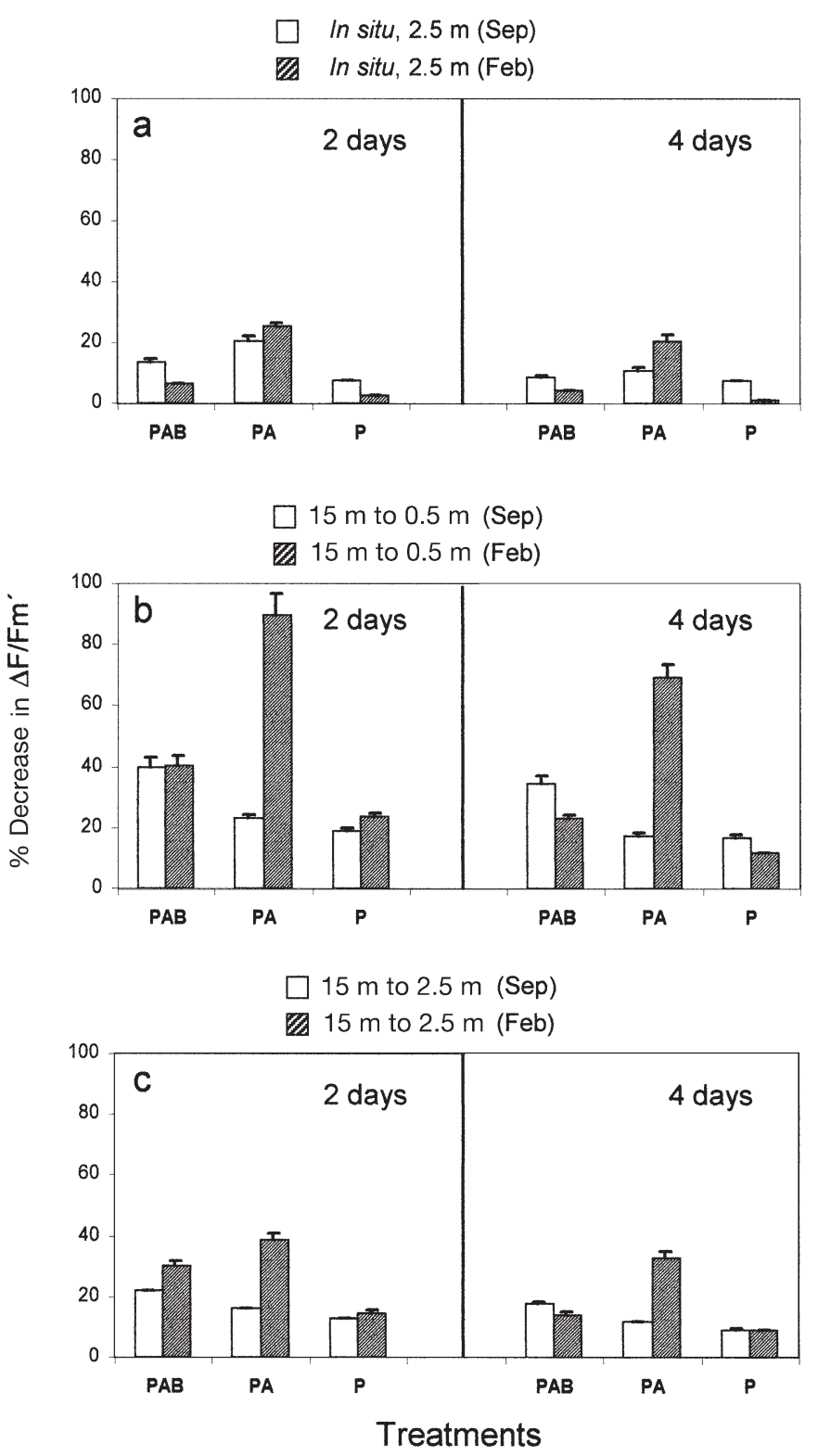

Fig. 4. Posidonia oceanica. Percentage decrease in $\Delta F / F_{\mathrm{m}}{ }^{\prime}$ at noon in (a) plants at their natural growth site (2.5 m depth), and shoots transferred from (b) 15 to 0.5 and (c) $2.5 \mathrm{~m}$ depth. The seagrass was exposed for 2 and $4 \mathrm{~d}$ to full solar irradiance (PAB), solar irradiance without UV-B (PA) and solar irradiance without UVR (P)

noon in both seasons. Thus, dynamic photoinhibition is expected at the natural site of growth of $P$. oceanica

ETR (calculated in this case using the values of incident solar irradiance at each season) was significantly higher (Tukey's test, $\mathrm{p}<0.01$ ) in summer than in winter, due to higher irradiation in September. In spite of the decrease in the effective quantum yield at noon, no parallel decay of ETR was observed at any season during the noon hours (Fig. 3b). Maximal ETR and $E_{\mathrm{k}}$ (under LED light) were about 3 times higher in summer than in winter (Fig. 3c and Table 2). The photoinhibition irradiance in September was $\sim 540 \mu \mathrm{mol} \mathrm{m}^{-2} \mathrm{~s}^{-1}$ and $220 \mu \mathrm{mol} \mathrm{m}^{-2} \mathrm{~s}^{-1}$ in February. ETR versus irradiance was also determined in plants incubated for $4 \mathrm{~d}$ at $2.5 \mathrm{~m}$ depth under P, PA and PAB (Table 2). Maximal ETR and $E_{\mathrm{k}}$ were significantly higher (Tukey's test, $\mathrm{p}<$ 0.05 ) in summer than in winter in all light treatments; moreover, the smallest values of ETR were found in the PA treatment in both seasons. Maximal ETR and $E_{\mathrm{k}}$ did not change significantly Tukey's test, $(p>0.05)$ after $4 \mathrm{~d}$ in PAB. However, after $4 \mathrm{~d}$ in PA, both ETR and $E_{\mathrm{k}}$ were significantly lower $(\mathrm{p}<0.05)$ than initial values (Table 2). Maximal ETR was highest and $E_{\mathrm{k}}$ lowest in shoots pre-incubated under P compared to other light treatments in both seasons.

The decrease in $\Delta F / F_{\mathrm{m}}{ }^{\prime}$ at noon in Posidonia oceanica growing at $2.5 \mathrm{~m}$ was significantly higher (Tukey's test, $\mathrm{p}<0.05$ ) under PA in both seasons (a drop of about $20 \%$ from morning values: Fig. 4a) than under the other light treatments. However, under $\mathrm{P}$ and $\mathrm{PAB}$, the decrease was less than $20 \%$, being more pronounced in September than in February (Fig. 4a). Under P, the decrease in $\Delta F / F_{\mathrm{m}}{ }^{\prime}$ was significantly (Tukey's test, $\mathrm{p}<$ 0.05 ) higher in September than in February after both 2 and $4 \mathrm{~d}$. However, under PAB, significant differences (Tukey's test, $\mathrm{p}<0.05$ ) among seasons were observed only after $2 \mathrm{~d}$.

Table 2. Posidonica oceanica. Maximal electron transport rate $\left(\mathrm{ETR}_{\max }\right)$ and saturation irradiance for ETR $\left(E_{\mathrm{k}}\right)$ determined in plants collected from their natural growth site $(2.5 \mathrm{~m}$ depth $=$ initial), and after $4 \mathrm{~d}$ incubation at the same depth under full solar irradiance (PAB), solar irradiance without UV-B (PA) and solar irradiance without UV-A and UV-B (P). Experiments were conducted in September 1996 and February 1997. Means $( \pm \mathrm{SD})$ calculated from at least 4 replicates for each light treatment in independent samples. Means were compared by applying a Model I 2-way ANOVA and Tukey's HSD test. Same letters indicate no significant differences, different letters indicate significant differences at $p<0.05$

\begin{tabular}{|lcc|}
\hline Treatments & ETR $_{\max }$ & $E_{\mathrm{k}}$ \\
\hline Initial & & \\
$\quad$ September & $147.3 \pm 1.4^{\mathrm{a}}$ & $419.7 \pm 27.9^{\mathrm{a}}$ \\
February & $28.8 \pm 2.7^{\mathrm{b}}$ & $80.5 \pm 7.0^{\mathrm{b}}$ \\
$\mathbf{4}$ d in PAB & & \\
$\quad$ September & $133.5 \pm 10.5^{\mathrm{a}}$ & $300.3 \pm 28.5^{\mathrm{a}}$ \\
$\quad$ February & $33.8 \pm 3.5^{\mathrm{b}}$ & $118.5 \pm 14.7^{\mathrm{b}}$ \\
$\mathbf{4}$ d in PA & & \\
$\quad$ September & $113.5 \pm 8.9^{\mathrm{c}}$ & $380.5 \pm 23.0^{\mathrm{c}}$ \\
$\quad$ February & $29.8 \pm 3.7^{\mathrm{d}}$ & $148.5 \pm 10.5^{\mathrm{d}}$ \\
$\mathbf{4}$ d in P & & \\
$\quad$ September & $225.6 \pm 15.3^{\mathrm{e}}$ & $285.3 \pm 15.9^{\mathrm{a}}$ \\
February & $58.31 \pm 4.5^{\mathrm{f}}$ & $105.5 \pm 13.6^{\mathrm{b}, \mathrm{e}}$ \\
\hline
\end{tabular}


The percentage decrease in $\Delta F / F_{\mathrm{m}}{ }^{\prime}$ was significantly higher (Tukey's test, $\mathrm{p}<0.05$ ) in seagrasses transferred from 15 to $0.5 \mathrm{~m}$ (Fig. $4 \mathrm{~b}$ ) or to $2.5 \mathrm{~m}$ (Fig. 4c) than in plants incubated at $2.5 \mathrm{~m}$ (Fig. 4a). The decrease was significantly higher in plants transferred from $0.5 \mathrm{~m}$ (Tukey's test, p < 0.05) than in those growing at $2.5 \mathrm{~m}$, and always more pronounced under PA than under $\mathrm{P}$ and $\mathrm{PAB}$ in February. However, in September, the decrease in $\Delta F / F_{\mathrm{m}}{ }^{\prime}$ was significantly higher (Tukey's test, $\mathrm{p}<0.05)$ in PAB than in PA or P in plants transferred from 0.5 or $2.5 \mathrm{~m}$ to $15 \mathrm{~m}$. The lowest decrease was found in the P treatment, indicating that photosynthetic efficiency was affected by UV. Moreover, the negative effects of UV-A radiation were more pronounced in the absence of UV-B. Thus, UV-B seemed to be necessary to partially ameliorate the photoinhibitory effect of UV-A. In the PA treatment, the decrease was significantly more pronounced (Tukey's test, $\mathrm{p}<0.05$ ) in February than in September, while no significant seasonal differences appeared in the $\mathrm{P}$ and $\mathrm{PAB}$ treatments. The percentage decrease in $\Delta F / F_{\mathrm{m}}{ }^{\prime}$ in shoots transferred from 15 to $0.5 \mathrm{~m}$ was significantly higher $(\mathrm{p}<0.05)$ under PAB than under $\mathrm{P}$ after both 2 and $4 \mathrm{~d}$ and in both seasons. In February, the decrease in $\Delta F / F_{\mathrm{m}}{ }^{\prime}$ under $\mathrm{PA}$ or $\mathrm{P}$ was significantly higher (Tukey's test, $\mathrm{p}<0.05$ ) after $2 \mathrm{~d}$ than that after $4 \mathrm{~d}$; however, this was not the case in September. The absence of UV-B radiation seemed to have more quantitative effects in winter than in summer. The reduction in the decrease in $\Delta F / F_{\mathrm{m}}{ }^{\prime}$ with time in plants transferred from 15 to 0.5 and $2.5 \mathrm{~m}$ (lower inhibition after $4 \mathrm{~d}$ at the new depth: Fig. 4b,c), might indicate partial acclimation to high irradiance in transferred plants.

Recovery of the $\Delta F / F_{\mathrm{m}}$ ' decrease was significantly (Tukey's test, $\mathrm{p}<0.05$ ) lower in plants transferred from $15 \mathrm{~m}$ than in those living at $2.5 \mathrm{~m}$ depth (Fig. 5). Seagrasses collected at $2.5 \mathrm{~m}$ depth showed a higher capacity for recovery than those transferred from 15 to 0.5 or to $2.5 \mathrm{~m}$. At $2.5 \mathrm{~m}$, recovery was significantly higher (Tukey's test, $\mathrm{p}<0.05$ ) in February than in September after $4 \mathrm{~d}$. In plants growing at $2.5 \mathrm{~m}$, the recovery in the afternoon was similar, close to $100 \%$, independent of light treatment and season. In plants transferred from 15 to $0.5 \mathrm{~m}$ in September, recovery was significantly higher (Tukey's test, p < 0.05) in PA and $\mathrm{P}$ than in $\mathrm{PAB}$ after both 2 and $4 \mathrm{~d}$. Recovery was higher (Tukey's test, $\mathrm{p}<0.05$ ) in September than in February under PA after both 2 and $4 \mathrm{~d}$. Under $\mathrm{P}$, significant differences (Tukey's test, $\mathrm{p}<0.05$ ) in September compared to February were found only after $4 \mathrm{~d}$. In plants transplanted from $15 \mathrm{~m}$ to $2.5 \mathrm{~m}$, after $2 \mathrm{~d}$, recovery was significantly higher (Tukey's test, p < 0.05 ) under $\mathrm{PA}$ and $\mathrm{P}$ than under $\mathrm{PAB}$; however after $4 \mathrm{~d}$ no significant differences among treatments were found. Thus, in transferred plants, recovery increased when the incubation period was extended to $4 \mathrm{~d}$, indicating acclimation to high irradiance (Fig. 5b,c).

\section{Decrease and recovery of $\Delta F / F_{m}$ ' after short-term (30 min) exposure to solar irradiance}

As part of the inhibition/recovery experiments, leaves of Posidonia oceanica were exposed for $30 \mathrm{~min}$ to solar irradiance at the water surface. A significant decrease in $\Delta F / F_{\mathrm{m}}{ }^{\prime}$ (Tukey's test, $\mathrm{p}<0.05$ ) in $P$. oceanica collected from $2.5 \mathrm{~m}$ was observed after $30 \mathrm{~min}$ exposure at the water surface at noon (Fig. 6). The decrease was significantly higher (Tukey's test, p < 0.05) in February than in September, although solar irradiance during exposure was higher in September
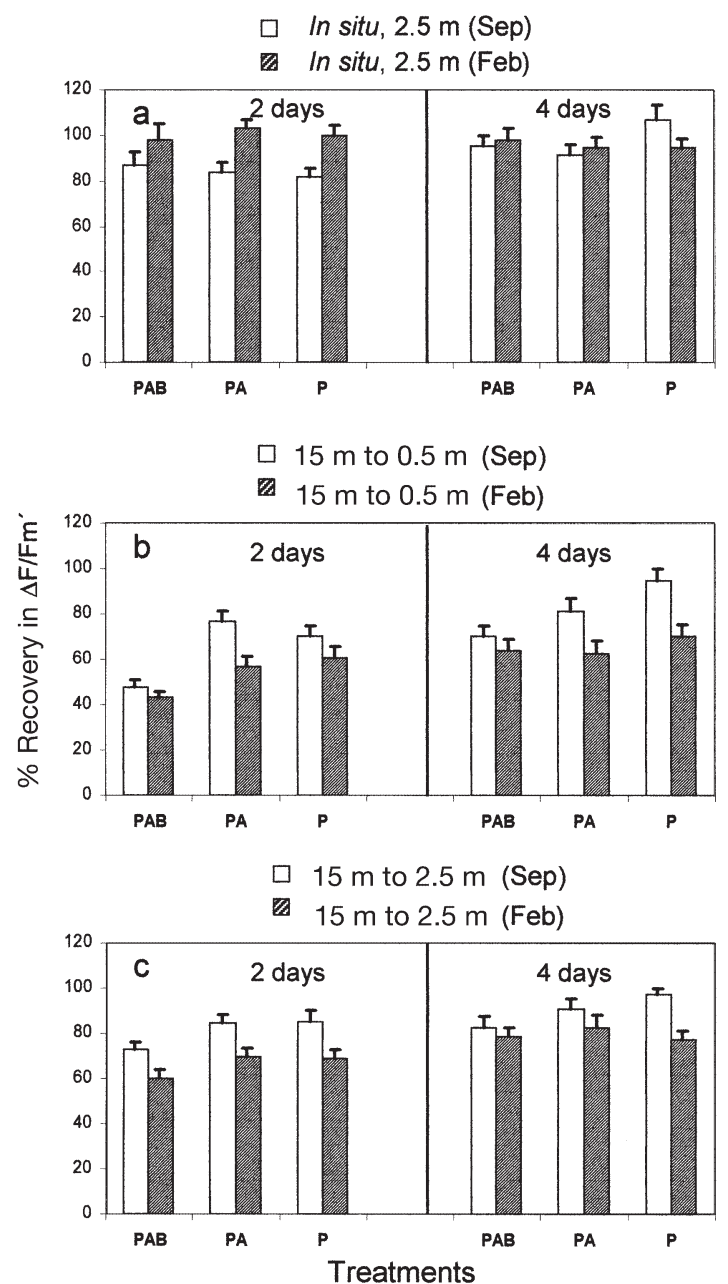

Fig. 5. Posidonia oceanica. Percentage recovery in $\Delta F / F_{\mathrm{m}}{ }^{\prime}$ in the afternoon in (a) shoots collected at their natural growth site $(2.5 \mathrm{~m}$ depth), and shoots transferred from (b) 15 to 0.5 and (c) $2.5 \mathrm{~m}$ depth. The seagrasses were exposed for 2 and $4 \mathrm{~d}$ to full solar irradiance (PAB), solar irradiance without UV$\mathrm{B}$ (PA) and solar irradiance without UVR (P) 


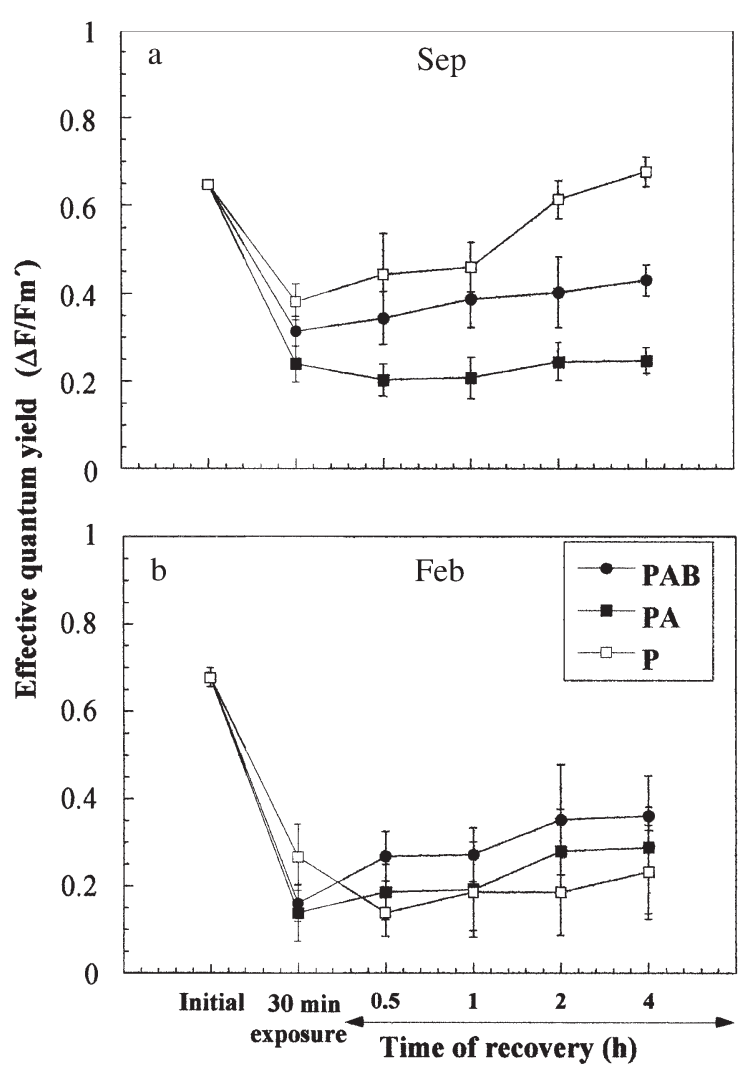

Fig. 6. Posidonia oceanica. Effective quantum yield $\left(\Delta F / F_{\mathrm{m}}{ }^{\prime}\right)$ of plants from $2.5 \mathrm{~m}$ depth exposed to a short-term (30 min) high irradiance treatment (exposure in surface waters at noon time) and during recovery (exposure to unfiltered solar irradiance in the shade at ca. $50 \mu \mathrm{mol} \mathrm{m} \mathrm{m}^{-2} \mathrm{~s}^{-1}$ ). The experiments were conducted in (a) September 1996 and (b) February 1997. During the high-irradiance treatments, shoots were exposed to $\mathrm{PAB}, \mathrm{PA}$ and $\mathrm{P}$

than in February. At noon, PAR irradiance was 450 and $307 \mathrm{~W} \mathrm{~m}^{-2}$, UV-A was 42 and $29 \mathrm{~W} \mathrm{~m}^{-2}$, and UV-B was 2.0 and $1.2 \mathrm{~W} \mathrm{~m}^{-2}$ in September and February respectively.

After 30 min exposure, recovery of $\Delta F / F_{\mathrm{m}}{ }^{\prime}$ was computed during the next $4 \mathrm{~h}$, with the plants exposed to low solar irradiance. Recovery was completed only in the P treatment in September (Fig. 6a). In February, recovery was very low in all the cases ( 29 to $51 \%$ of the initial values, depending on light treatment). In September, recovery of $\Delta F / F_{\mathrm{m}}{ }^{\prime}$ was significantly higher (Tukey's test, $\mathrm{p}<0.05$ ) under $\mathrm{P}$ and PAB than under PA. However, in February, the recovery was similar under all light treatments (Fig. 6b). Thus, short exposure to high irradiance promoted a significant decrease in $\Delta F / F_{\mathrm{m}}{ }^{\prime}$, with almost no recovery. This result differed from that for Posidonia oceanica at its natural growth site at $2.5 \mathrm{~m}$ (Figs. $4 \mathrm{a} \& 5 \mathrm{a}$ ) where full recovery occurred.
In order to investigate the effects of the absence of UV on $\Delta F / F_{\mathrm{m}}{ }^{\prime}$, plants previously incubated for $4 \mathrm{~d}$ at $2.5 \mathrm{~m}$ under $\mathrm{P}, \mathrm{PA}$ and PAB were submitted to shortterm exposure $(30 \mathrm{~min}$ ) of high solar irradiance (at the water surface) of P, PA and PAB (Fig. 7). Highest photoinhibition was produced in P-pretreated plants. After preincubation for $4 \mathrm{~d}$ under PAB (Fig. 7 a), the decrease in $\Delta F / F_{\mathrm{m}}$ ' was significantly higher (Tukey's test, $\mathrm{p}<0.05)$ after short-term exposure $(30 \mathrm{~min})$ in $\mathrm{PAB}$ than that under PA and $\mathrm{P}$; the decrease in $\Delta F / F_{\mathrm{m}}{ }^{\prime}$ was significantly higher (Tukey's test, $\mathrm{p}<0.05$ ) in February than in September under only PA and P exposure.

After preincubation for $4 \mathrm{~d}$ in PA significant differences between February and September (Tukey's test, $\mathrm{p}<0.05$ ) were only found under short-term exposure in P. The decrease in $\Delta F / F_{\mathrm{m}}{ }^{\prime}$ was significantly higher (Tukey's test, $\mathrm{p}<0.05$ ) after short exposure to PAB than to PA and P. Finally, after preincubation for $4 \mathrm{~d}$ under $\mathrm{P}$ no significant differences among the light treatments
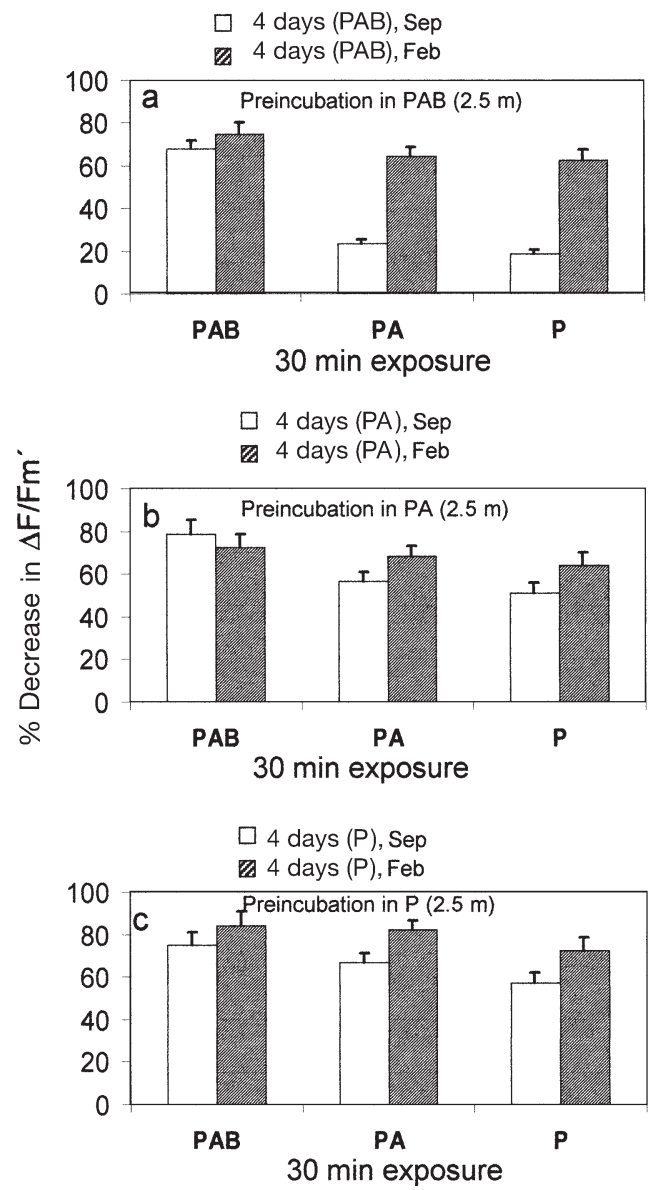

Fig. 7. Posidonia oceanica. Percentage decrease in $\Delta F / F_{\mathrm{m}}{ }^{\prime}$ after 30 min exposure to high solar irradiance in PAB, PA and $\mathrm{P}$ treatments. Shoots were previously acclimated for $4 \mathrm{~d}$ at $2.5 \mathrm{~m}$ to $\mathrm{PAB}, \mathrm{PA}$ and $\mathrm{P}$ 
were observed within either month. Significant differences $(p<0.05)$ between February and September were found for short-term exposure under PA and P but not under PAB.

\section{DISCUSSION}

Posidonia oceanica seems to be well acclimated to the high irradiance conditions of Cabo de Gata (southern Spain), since it shows a relatively low decrease in effective quantum yield at noon and full recovery in the afternoon in plants incubated in situ. The decrease in $\Delta F / F_{\mathrm{m}}{ }^{\prime}$ was higher in September than in February, since both solar radiation and transparency of the water column were higher in September than in February. Plants transferred from 15 to $2.5 \mathrm{~m}$ showed a higher decrease than those from $2.5 \mathrm{~m}$, indicating a partial loss of photoprotective mechanisms in $P$. oceanica from deeper waters. Similar results have been reported by Ralph et al. (1998), who found that several seagrasses (including P. oceanica) from shallow waters had a higher capacity for non-photochemical quenching (e.g. protection from excessive radiant energy) than seagrasses from deeper waters. Also, Dennison \& Alberte (1986) found lower photosynthetic rates when transplanting Zostera marina plants from 7 and $10 \mathrm{~m}$ depth to shallow waters. The photoprotective mechanisms seem to be rapidly stimulated, since inhibition decreased and recovery increased when the period after transference was extended from 2 to $4 \mathrm{~d}$. Öquist et al. (1992a) suggested that there are mechanistic differences in the photoinhibition of sun and shade plants. Specifically, they proposed that sun plants can rapidly replace photoinhibited PSII reaction centres with photochemically active ones by means of an active repair cycle. In shade plants, however, this cycle would be less developed, with the PSII reaction centres that become inhibited providing protection to the remaining active centres by non-photochemical dissipation of excess excitation energy. This rapid acclimation to high irradiance conditions represents a strategy for survival in waters that are highly transparent to UV. In Cabo de Gata, $1 \%$ of incident UV-B radiation penetrated to $11 \mathrm{~m}$ in February and to $22 \mathrm{~m}$ in September. Even though UV-B accounts for only a very small fraction of solar irradiance, it has been shown to have a considerable effect on the photosynthesis of macroalgae, inducing a significant decrease on their photosynthetic $\mathrm{O}_{2}$ production (see Franklin \& Forster 1997, Häder \& Figueroa 1997).

There is limited information concerning the effects of UV radiation on marine angiosperms. Trocine et al. (1981) studied UV tolerance and photorepair capabilities of 3 species, and noted that Halodule wrightii had a high photosynthetic tolerance to UV-B, whereas Syringodium filiforme and Halophila engalmanni were more sensitive. It was speculated that all 3 species relied on epiphytic shading to reduce the degree of exposure to UV (Trocine et al. 1981). Dawson \& Dennison (1996) showed different degrees of photoinhibition in several seagrasses in response to increased $(+25 \%)$ PAR and UVR. Halophila ovalis and Halodule uninervis were the most sensitive species, exhibiting the largest decrease in photosynthetic efficiency and chloroplast density. In the present study, we found different effects in Posidonia oceanica to those observed in macroalgae (Häder \& Figueroa 1997). The presence of UV-A in the absence of UV-B (PA treatment) induced the highest degree of photoinhibition in P. oceanica (Fig. 4). Also, UVR might be involved in the stimulation of photoprotection mechanisms, since short-term exposure to high solar irradiance induced higher photoinhibition in plants preincubated $(4 \mathrm{~d})$ under $P$ than those preincubated under PA or PAB (Figs. $5 \& 7$ ). These results contrast with those reported for most macroalgae, in which the largest photoinhibition occurred under full solar irradiance (Wood 1987, Häder et al. 1996, 1997). However, recently, a beneficial role of UV-B radiation in the repair process of photosynthesis has also been suggested (Flores-Moya et al. 1999). In P. oceanica, photoprotection mechanisms could also be stimulated by UVradiation. In addition, some enzymatic activities (e.g. nitrate reductase and carbonic anhydrase) are also stimulated by UV-A or UV-B radiation in several macroalgae (Flores-Moya et al. 1998, Gómez et al. 1998) and in P. oceanica (Viñegla 2000).

The photoprotection mechanisms of Posidonia oceanica are still unknown, but according to our results the presence of UV-B seems to diminish the degree of photoinhibition at noon. However, UV-B seems not to be essential to recovery, since this was higher under PA than under PAB. The photoinhibition and recovery processes would therefore seem to be differently photoregulated. Daily dynamic photoinhibition (Osmond 1994), including an increase of non-photochemical quenching at noon (data not shown), can constitute, per se, a photoprotection mechanism. Öquist et al. (1992b) indicated that photoinhibition of photosynthesis represents a mechanism for long-term regulation of the PSII. Structural changes in the D1 protein facilitates the formation of a population of dissipative PSII centres that do not participate in linear electron transport to PSI (Critchley \& Rusell 1994). Dynamic photoinhibition following a diurnal pattern has been found in several macroalgae (Henley et al. 1991, Figueroa et al. 1997, Häder et al. 1996, 1997): the algae were photoinhibited by excess light at noon, followed by recovery in the afternoon of effective quantum yield and photosynthesis. High solar irradiance reduces the photosyn- 
thetic activity of marine algae (Hanelt et al. 1994, Häder et al. 1996, 1997, Hanelt 1996), as demonstrated by a decrease in the effective quantum yield and photosynthetic $\mathrm{O}_{2}$ production. As reported for macroalgae (Häder \& Figueroa 1997), plants growing at the surface are much more resistant to photoinhibition than are deep-water species. Hanelt et al. (1993) and Häder \& Schäfer (1994) found no significant recovery of photosynthesis in red algae exposed to full solar irradiance, indicating permanent photodamage rather than photoinhibition.

Another possible mechanism for protection is the accumulation of UV-absorbing substances. Prevention of UV damage by screening substances has been reported for several marine and terrestrial autotrophic organisms (Dunlap \& Chalker 1986, Büdel et al. 1997, Karsten et al. 1998). Among these, mycosporine-like aminoacids (MAAs) have been recognised as performing an active photoprotective role. In Posidonia oceanica, a very high content of other UV-absorbing substances has been detected (e.g. polyphenolic compounds: Abdala \& Figueroa unpubl. data), which play a possible photoprotective role against UV radiation. Trocine et al. (1981) suggested that the presence of flavonoids may reduce the degree of UV-induced inhibition in marine angiosperms, but they presented no data on the concentration of such UV-absorbing substances. Dawson \& Dennison (1996) found that several seagrasses with a high tolerance to UVR (e.g. Zostera capricorni, Cymodocea serrulata and Syringodium isoetifolim) greatly increased the production of UV-blocking pigments in response to UV radiation.

In Posidonia oceanica the capacity for acclimation to high solar irradiance is clearly higher in summer than in winter. This was demonstrated by the different experiments carried out in this study: (1) In general, there was a higher decrease in $\Delta F / F_{\mathrm{m}}{ }^{\prime}$ and a higher recovery in September than in February in both Posidonia oceanica from $2.5 \mathrm{~m}$ and in shoots transferred from 15 to 0.5 and $2.5 \mathrm{~m}$ (Figs. 4 \& 5). (2) There was a lower decrease in $\Delta F / F_{\mathrm{m}}{ }^{\prime}$ after short-term exposure (30 min in surface waters) to high solar irradiance and higher recovery (after $4 \mathrm{~h}$ under low irradiance) in September than in February (Fig. 6). (3) There was a higher maximal ETR and higher $E_{\mathrm{k}}$ in September than in February (Fig. 3 \& Table 2).

In addition to light, temperature is another environmental factor that can affect photosynthetic rate and photoinhibition (Logan et al. 1999). Whereas the photophysical events of light-capture and charge separation are not strongly influenced by cold temperatures, $\mathrm{Q}_{10}$ effects upon enzymes of the Calvin cycle limit photosynthetic rates (Leegod 1995). Low temperatures can induce a decrease in the optimal quantum yield through an accumulation of photochemically inactive reaction centres of the PSII (Krause 1994). Increasing temperature stimulates respiration and the repair process (resynthesis of the D1 protein) (Krause 1994). Ekelund (2000) discussed the importance of respiration in the repair mechanisms of photoinhibition for phytoplankton. The differences between the electron transport rates in summer and winter could be also due to temperature. However, in Cabo de Gata waters, differences between winter and summer temperatures are not very high (only $6 \pm 1^{\circ} \mathrm{C}$ ) and no drastic temperature effects on photosynthesis, as reported for plants of colder systems (Krause 1994, Logan et al. 1999) would be expected. A sufficiently high ambient temperature may be necessary for high activity of the dark reactions, so that the marine macrophytes do not suffer from light stress on a sunny day in the Mediterranean zone. If most of the absorbed energy can be used for photochemical reactions, photosynthesis is not severely stressed by light and, hence, photoinhibition of PSII would not occur.

In this work, we have shown that the response to high UVR in Posidonia oceanica differs from that of other marine macrophytes in southern Spain (Figueroa et al. 1997, Häder \& Figueroa 1997, Figueroa 1998, Flores-Moya et al. 1998, Häder et al. 1998). In general, in most macroalgae that have been analysed, PAB induces higher photoinhibition than PA or P. In contrast, in $P$. oceanica, the relatively rapid alteration in its tolerance to high irradiance, e.g. preincubation under PAR for $4 \mathrm{~d}$ or exposure to only PAR + UV-A, indicates that the presence of UV-B is necessary for maintaining or stimulating photorepair mechanisms. Thus, the high levels of UV-B during the summer may activate these dynamic photoinhibition mechanisms, since the radiation is high enough to reach young leaves that are not directly exposed. The availability of UV-B is a result of very clear waters. This indicates that UVR and high PAR in the field could act as triggers for the induction of photoprotective mechanisms against UV radiation. Hanelt et al. (1997) showed that polar macroalgae cultivated for a long period in the laboratory retained certain genetic adaptations to the natural environment. In $P$. oceanica, light environmental signals (trigger elements) seem also to be necessary to stimulate photoprotective mechanisms during photoinhibition and recovery. One of these possible signals could be the ratio UVR/PAR. Smith et al. (1992) indicated that changes in the UVR/PAR of natural radiation better explained photoinhibition induced by solar irradiance than the absolute amount of PAR or UVR. The ratio UVR/PAR could act as an environmental signal, and both photoinhibition and photoprotection mechanisms could be modulated by variations in this ratio. These variations have been shown to occur through the day and throughout the year, and to be altered by the 
presence of clouds (Madronich 1993, Gautier et al. 1994). As an analogy, it is known that in both terrestrial plants (Smith 1993) and algae (Rüdiger \& LópezFigueroa 1992, Figueroa 1996) the environmental variation in another light ratio (e.g. red:far-red) acts as an environmental signal. The ratio among different light broadbands is dependent on the level of radiation, which is variable over the year. Thus, the absence of an environmental signal in winter and autumn may be due to the low irradiance during these seasons, while in summer UV-B levels are sufficiently high to activate photoprotection mechanisms that are present, but not active, in winter.

In conclusion, our results suggest that the presence of UVR is necessary for the activation of photoprotection mechanisms in marine seagrasses; however, more research is necessary to discover the exact roles of UVR and of the UVR:PAR ratio as environmental signals.

Acknowledgements. This work was supported by the Ministry of Education and Science of Spain (Project CICYT AMB97/1021-C02-01), by the European Union (Environment and Climate Programme, ENV4-CT96-0188; DG XII), and by the FEDER Project (1FD97-0824).

\section{LITERATURE CITED}

Alcoverro T, Duarte CM, Romero J (1995) Annual growth dynamics of Posidonia oceanica: contribution of largescales versus local factors seasonality. Mar Ecol Prog Ser 120:203-210

Beer S, Björk M (2000) Measuring rates of photosynthesis of two tropical seagrasses by pulse amplitude modulated (PAM) fluorometry. Aquat Bot 66:69-76

Beer S, Vilenkin B, Weil A, Vete M, Susel L, Eshel A (1998) Measuring photosynthetic rates in seagrasses by pulse amplitude modulated (PAM) fluorometry. Mar Ecol Prog Ser 174:293-300

Booth BC, Lewin J, Postel JR (1994) Temporal variation in the structure of autotrophic and heterotrophic communities in the sub-Arctic Pacific. Prog Oceanogr 32:57-99

Boudouresque CF, Meinesz A, Fresi E (1989) II International workshop on Posidonia oceanica beds. GIS Posidonie, Marseille, France

Büchel C, Wilhelm C (1993) In vivo analysis of slow chlorophyll fluorescence induction kinetics in algae: progress, problems and perspectives. Photochem Photobiol 58: 137-148

Büdel B, Karsten U, García-Pichel F (1997) Ultravioletabsorbing scytonemin and mycoporine-like aminoacid derivatives in exposed, rock-inhabiting cyanobacterial lichens. Oecologia 112:165-172

Critchley C, Rusell AW (1994) Photoinhibition of photosynthesis in vivo: the role of protein turnover in photosystem II. Physiol Plant 92:188-196

Dawson SP, Dennison WC (1996) Effects of ultraviolet and photosynthetically active radiation in five seagrass species. Mar Biol 125:629-638

Dennison WC, Alberte RS (1986) Photoadaptation and growth of Zostera marina L. (eelgrass) transplants along a depth gradient. J Exp Mar Biol Ecol 98:265-282
Dunlap WC, Chalker BE (1986) Identification and quantification of near-UV absorbing compounds (S-320) in hermatypic scleractinian. Coral Reefs 5:155-159

Ekelund NGA (2000) Interaction between photosynthesis and 'light-enhanced dark respiration' (LEDR) in the flagellate Euglena gracilis after irradiation with ultraviolet radiation. J Photochem Photobiol B Biol 55:63-69

Enríquez S, Duarte CM, Sand-Jensen K (1995) Patterns in the photosynthetic metabolism of Mediterranean macrophytes. Mar Ecol Prog Ser 119:243-252

Figueroa FL (1996) Underwater light signals: role of algal photoreceptors in the natural environment. G Bot Ital 130: 608-623

Figueroa FL (1998) Underwater light and primary production. In: Nolan CV, Häder DP (eds) Role of solar UV-B on ecosystems effects on ecosystems. Research UE report 30: 121-123, Luxemburg

Figueroa FL, Salles S, Aguilera J, Jiménez C, Mercado J, Viñegla B, Flores-Moya A, Altamirano M (1997) Effects of solar irradiance on photoinhibition and pigmentation in the red alga Porphyra umbilicalis. Mar Ecol Prog Ser 151: $81-90$

Flores-Moya A, Gómez I, Viñegla B, Altamirano M, PérezRodríguez E, Maestre C, Caballero RM, Figueroa FL (1998) Effects of solar irradiance on the endemic Mediterranean red alga Rissoella verruculosa: photosynthesis performance, pigment content and the activities of enzymes related to nutrient uptake. New Phytol 139:673-683

Flores-Moya A, Hanelt D, Figueroa, FL, Altamirano M, Viñegla B, Altamirano M, Salles S (1999) Involvement of solar UV-B radiation in recovery of inhibited photosynthesis in brown alga Dictyota dichotoma (Hudson) Lamouroux. J Photochem Photobiol B Biol 49:129-135

Franklin LA, Forster RM (1997) The changing irradiance environment: consequences for marine macrophyte physiology, productivity and ecology. Eur J Phycol 32:207-232

Gautier C, He G, Yang S, Lubin D (1994) Role of clouds and ozone on spectral ultraviolet-B radiation and biologically effective UV dose over Antarctica. In: Weiler CS, Penhale PA (eds) Ultraviolet radiation in Antarctica: measurements and biological effects. Antarct Res Ser 62:83-91

Genty B, Briantis JM, Baker NR (1989) The relationship between the quantum yield of photosynthetic electron transport and quenching of chlorophyll fluorescence. Biochim Biophys Acta 990:87-92

Gómez I, Pérez-Rodríguez E, Viñegla B, Figueroa FL, Karsten U (1998) Effects of solar irradiance on photosynthesis, UVabsorbing compounds and enzyme activities of the green alga Dasycladus vermicularis from southern Spain. J Photochem Photobiol B Biol 47:46-57

Häder DP, Figueroa FL (1997) Photoecophysiology of macroalgae. Photochem Photobiol 66:1-14

Häder DP, Schäfer J (1994) Photosynthetic oxygen production in macroalgae and phytoplankton under solar irradiation. J Plant Physiol 144:293-299

Häder DP, Worrest RC (1991) Effects of enhanced solar-ultraviolet radiation on aquatic ecosystems. Photochem Photobiol 53:717-725

Häder DP, Porst M, Herrmann H, Schäfer J, Santas R (1996) Photoinhibition in the Mediterranean green alga Halimeda tuna Ellis et Sol measured in situ. Photochem Photobiol 64:428-434

Häder DP, Porst M, Herrmann H, Schäfer J, Santas R (1997) Photosynthesis of the Mediterranean green alga Caulerpa prolifera measured in the field under solar irradiation. J Photochem Photobiol B Biol 37:66-73

Häder DP, Lebert M, Figueroa FL, Jiménez C, Viñegla B, 
Pérez-Rodríguez E (1998) Photoinhibition in Mediterranean macroalgae by solar irradiance on site by PAM fluorescence. Aquat Bot 61:225-236

Hanelt D (1996) Photoinhibition of photosynthesis in marine macroalgae. Sci Mar 60(Suppl 1):243-248

Hanelt D (1998) Capability of dynamic photoinhibition in Arctic macroalgae is related to their depth distribution. Mar Biol 131:361-369

Hanelt D, Li J, Nultsch W (1994) Tidal dependence of photoinhibition in marine macrophytes of the South China Sea. Bot Acta 107:66-72

Hanelt D, Huppertz K, Nultsch W (1993) Daily course of photosynthesis and photoinhibition in marine macroalgae investigated in the laboratory and field. Mar Ecol Prog Ser 97:31-37

Hanelt D, Melchersmann B, Wiencke C, Nultsch W (1997) Effects of high light stress on photosynthesis of polar macroalgae in relation to depth distribution. Mar Ecol Prog Ser 149:255-266

Henley WJ, Levavasseur G, Franklin LA, Lindley ST, Ramus J, Osmond CB (1991) Diurnal responses of photosynthesis and fluorescence in Ulva rotundata acclimated to sun and shade in outdoor culture. Mar Ecol Prog Ser 75:19-28

Jassby AD, Platt T (1976) Mathematical formulation of the relationship between photosynthesis and light for phytoplankton. Limnol Oceanogr 21:540-547

Karsten U, Sawall D, Hanelt D, Bischop K, Figueroa FL, Flores-Moya A, Wiencke C (1998) An inventory of UV-absorbing mycosporine-like amino acids in macroalgae from polar to warm-temperate waters. Bot Mar 41:443-453

Kirk JTO (1994) Light and photosynthesis in the aquatic environment. 2nd edn. Cambridge University Press, Cambridge, UK

Krause GH (1994) Photoinhibition induced by low temperature. In: Baker NR, Bowyer JR (eds) Photoinhibition of photosynthesis from molecular mechanisms to the field. BIOS Scientific Publishers Ltd., Oxford, p 331-348

Leegod RC (1995) Effects of temperature on photosynthesis and photorespiration. In: Smirnoff N (ed) Environmental and plant metabolism. BIOS Scientific Publishers, Oxford, p 45-63

Logan BA, Demmig-Adams B, Adams II WW (1999) Acclimation of photosynthesis to the environment. In: Singhal GS, Renger G, Sopory SK, Irrgang KD, Govindjee G (eds) Photosynthesis and photomorphogenesis. Narosa Publishing House, New Delhi, p 477-511

Madronich S (1993) The atmosphere and UV-B radiation at ground level. In: Young AR, Björn LO, Moan J, Nultsch W (eds) Environmental UV photobiology. Plenum Press, New York, p 1-39

Maegawa M, Kunieda M, Kida W (1993) The influence of ultraviolet radiation on the photosynthetic activity of several algae from different depths. Jpn J Phycol 41: $207-214$

Öquist G, Anderson JM, McCaffery S, Chow WS (1992a) Mechanistic differences in photoinhibition of sun and shade plants. Planta 184:538-544

Öquist G, Chow WS, Anderson JM (1992b) Photoinhibition of photosynthesis represents a mechanism for the long-term regulation of photosystem II. Planta (Berl) 186:450-460

Orce VL, Helbling EW (1997) Latitudinal UVR-PAR measurements in Argentina: extent of the 'ozone hole'. Global Planet Change 15:113-121

Osmond CB (1994) What is photoinhibition? Some insights from comparisons shade and sun plants. In: Baker NR, Bowyer JR (eds) Photoinhibition of photosynthesis from molecular mechanisms to the field. BIOS Scientific Publishers Ltd., Oxford, p 1-24

Ott JA (1980) Growth and production in Posidonia oceanica (L.) Delile. PSZN I: Mar Ecol 1:47-64

Pergent G, Romero JM, Pergent-Martini C, Mateo MA, Bouderesque, C-F (1994) Primary production, stocks and fluxes in the Mediterranean seagrass Posidonia oceanica. Mar Ecol Prog Ser 106:139-146

Phillips RC, McRoy CP (eds) (1980) Handbook of seagrass biology: an ecosystem perspective. Garland STPM Press, New York

Platt J, Gallegos C, Harrison S (1980) Photoinhibition of photosynthesis in natural assemblages of marine phytoplankton. J Mar Res 38:687-701

Ralph PJ, Burchett MD (1995) Photosynthetic responses of the seagrass Halophyla ovalis (R. Br.) Hook. F. to high irradiance stress using chlorophyll a fluorescence. Aquat Bot 51: 55-66

Ralph PJ, Gademann R, Dennison WC (1998) In situ seagrass photosynthesis measured using a submersible, pulseamplitude modulated fluorometer. Mar Biol 132:367-373

Rüdiger W, López-Figueroa F (1992) Photoreceptors in algae. Photochem Photobiol 55:949-954

Schreiber U, Endo T, Mi H, Asada K (1986) Quenching analysis of chlorophyll fluorescence by saturation pulse method: particular aspects relating to eukariotic algae and cyanobacteria. Plant Cell Physiol 36:873-882

Shibata K (1957) Spectrophotometry of translucent biological materials - opal glass transmission method. Methods Biochem Anal 7:77-109

Smith H (1993) Sensing the light environment: the functions of phytochrome family. In: Shropshire W Jr, Mohr H (eds) Photomorphogenesis in plants, 2nd edn. Kluwer Academic Publishers, The Netherlands, p 377-416

Smith RC, Prézelin BB, Baker KS, Bidigare RR and 9 others (1992) Ozone depletion: ultraviolet radiation and phytoplankton biology in Antarctic waters. Science 255: 952-959

Sokal RR, Rolf FJ (1995) Biometry. the principles and practice of statistics in biological research, 3rd edn. WH Freeman \& Co., New York

Trocine RP, Rice RD, Wells GN (1981) Inhibition of seagrass by ultraviolet-B radiation. Plant Physiol (Wash DC) 68: $74-81$

Viñegla B (2000) Efecto de la radiación UV sobre actividades enzimáticas relacionadas con el metabolismo del carbono y el nitrógeno en macroalgas y fanerógamas marinas. PhD thesis, Universidad de Málaga

Wood WF (1987) Effect of solar ultraviolet radiation on the kelp Ecklonia radiata. Mar Biol 96:143-150

Submitted: May 3, 2000; Accepted: May 31, 2001

Proofs received from author(s): March 18, 2002 